\title{
Effect of a single injection of a long-acting gonadotropin-releasing hormone agonist on prepubertal male and female pigs on reproductive organs, growth performance and sensory qualities of pork roasts
}

\author{
J Reid ${ }^{1}$, JJ Dufour ${ }^{1}$, MA Sirard 2* \\ ' Département des sciences animales, université Laval; \\ ${ }^{2}$ Laboratoires d'ontogénie et reproduction, centre de recherche du CHUL, Sainte-Foy, $P Q$, Canada
}

(Received 5 May 1995; accepted 2 April 1996)

\begin{abstract}
Summary - Crossbred pigs $(n=200)$ were used to study the effects of a long-acting form of gonadotropin-releasing hormone $(\mathrm{GnRH})$ agonist on the reproductive systems of male and female pigs and their growth performance and sensory quality of pork roast. Treatment was a single injection of a controlled release formulation of $\mathrm{GnRH}$ agonist [D-Trp ${ }^{6}$, des-Gly $\left.{ }^{10}\right]-G n R H$ ethylamide to release $5 \mu \mathrm{g} /(\mathrm{kg} \times$ day) for 4 months beginning when the pigs were $66 \pm 2$ days old. Pigs were allocated to five groups of 40 animals each: males castrated (CM) at $13 \pm 2$ days, intact males (IM), treated males (TM), intact females (IF) and treated females (TF). Ovarian and uterine weights at slaughter averaged 3.67 and $79.8 \mathrm{~g}$, respectively, in IF compared with 1.38 and $26.5 \mathrm{~g}$ in TF $(P<0.05)$. Testicular weights were $203 \mathrm{~g}$ in IM and $36.8 \mathrm{~g}$ in TM $(P<0.05)$. Microscopic observations of the testes revealed an absence of sperm cells but the presence of germ cells. Steroid concentrations at slaughter from all pigs showed that intact males had significantly more testosterone in their serum $(26.36 \pm 9.87 \mathrm{nmol} / \mathrm{L})$ compared with TM, CM, IF or TF groups and that treated males had intermediate concentrations $(12.50 \pm 7.44 \mathrm{nmol} / \mathrm{L})$ higher $(P<0.05)$ than those in CM and TF. Administration of GnRH agonist during the growth period of male pigs had no consistent effect on growth performance, but as compared to IM pigs, some of the carcass charasteristics such as meat ratio (49.1 vs $50.2 \%$ in TM and IM; $P<$ $0.001)$, dressing percentage ( 77.5 vs $76.5 \%$ in $\mathrm{TM}$ and $\mathrm{IM} ; P<0.05)$ and average backfat $(20.8 \mathrm{vs}$ $17.6 \mathrm{~mm}$ in TM and IM; $P<0.05$ ) were modified by such a treatment. Meat quality, however, as determined by flavor and tenderness evaluations by sensory panelists, were similar $(P<0.05)$ in all groups and off-flavor scores were lower in TM than in IM $(P<0.001)$. As for males, backfat and meat ratio were different in TF compared to IF $(P<0.05)$ and roast juiciness was higher in TF than IF $(P<0.05)$. These results suggest that $\mathrm{GnRH}$ agonist can reduce gonadal secretory activity to castration levels during the growth period of prepubertal male pigs and could be an alternative to surgical castration in
\end{abstract}

\footnotetext{
* Correspondence and reprints
} 
the pork industry with no negative effects on growth and meat quality. No advantage to endocrine castration in females was found.

\title{
GnRH / pituitary / pig / castration / testis / steroid
}

\begin{abstract}
Résumé - L'effet d'une injection de GnRH à action prolongée sur les paramètres de croissance et reproducteurs chez des porcs prépubères. Dans cette étude nous avons utilisé deux cents porcelets mâles et femelles, issus de croisement de races, pour évaluer les effets d'une formule longue durée d'un agoniste de GnRH sur les tractus génitaux, les stérö̈des sanguins, les performances de croissance, les caractéristiques des carcasses et les qualités sensorielles des rôtis. Le traitement consistait en une injection, administrée lorsque les porcs étaient âgés de $66 \pm 2$ jours (j0), d'une formule planifiée pour relâcher $5 \mu \mathrm{g} /(\mathrm{kg} \times$ jour $)$ de l'agoniste de GnRH [D-Trp ${ }^{6}$, des-Gly'0]-GnRH ethylamide (Southern Res Ins, Birmingham, AL, États-Unis) sur une période de 4 mois. Les porcelets furent distribués dans un des cinq groupes suivants : 40 mâles castrés à l'âge de $13 \pm 2$ jours (CM), 40 mâles entiers (IM), 40 mâles traités (TM), 40 femelles entières (IF) et 40 femelles traitées (TF). Au moment de l'abattage, les ovaires, utérus et testicules ont été prélevés et pesés. Les concentrations des stéroïdes sanguins mesurées à l'abattage indiquent des différences significatives entre la testostérone et le $\Delta-4$ androsténedione ( $\mathrm{p}<0,05)$ pour les comparaisons suivantes: $C M$ vs IM, CM vs $T M$, $I M$ vs TM, IM vs IF, M vs TF et TM vs TF. Au moment de l'abattage, les ovaires et l'utérus pesaient en moyenne 3,67 et $79,8 \mathrm{~g}$ respectivement pour les IF comparativement à 1,38 et $26,5 \mathrm{~g}$ pour les TF ( $\mathrm{p}$ $<0,05)$. Le poids des testicules pour les $I M$ était de 203 et de $36,8 \mathrm{~g}$ pour les $T M(\mathrm{p}<0,05)$. L'examen histologique des ovaires indiquait une accumulation des follicules de petite taille chez les TF et l'absence de cellules spermatiques mais la présence de cellules germinales, une diminution du diamètre des tubules séminifères et une réduction de la quantité de liquide du lumen dans les testicules d'animaux traités. L'administration de l'agoniste du GnRH pendant la période de croissance des porcs mâles n'a pas eu d'effets marqués sur les performances de croissance, la qualité des carcasses ainsi que sur les qualités sensorielles de la viande à l'exception du gras dorsal qui était plus important chez les $T M$ et de l'arrière-goût qui était moindre chez les TM que chez les $I M(p<0,05)$. Les pointages obtenus lors de l'évaluation de la saveur et de la tendreté de la viande étaient similaires pour tous les groupes $(\mathrm{p}<0,05)$. Les résultats de cette recherche suggèrent qu'un agoniste du GnRH pourrait représenter une alternative à la castration chirurgicale en production porcine, facile d'application et sans effets négatifs sur la croissance et la qualité de la viande des porcs. Cependant, il ne semble y avoir aucun avantage à utiliser la castration endocrinienne chez les femelles.
\end{abstract}

\section{GnRH / pituitaire / porc / castration / testicule / utérus / ovaire}

\section{INTRODUCTION}

Some boar meat produces a strong, unpleasant cooking odor and taste called boar taint that is associated with fatty tissue (Bonneau, 1982). Desmoulin et al (1982) reported that at slaughter weight, $38 \%$ of intact males had boar taint compared with only $6 \%$ of females and castrated males. The main contributors to boar taint in pig fat are androstenone and skatole (for review, see Bonneau, 1982; Brooks and Pearson, 1986). Androstenone is produced principally in the testis, together with the hormonal steroids, androgens and estrogens, and it is stored in salivary glands and adipose tissues (Bonneau, 1988). Skatole is a product of bacterial degradation of tryptophan in the intestine. Little is known about the synthesis, regulation and storage of skatole in fat, but these factors seem to be dependent on testicle steroid production (Lundstrom et al, 1988).

Surgical castration within the first weeks after birth is the usual practice for the prevention of boar odor in pork meat (Brooks and Pearson, 1986). Castration of male pigs has been practiced to eliminate indiscrimi- 
nate breeding, and to reduce the possibility of boar taint in meat (Sather et al, 1991). On the other hand, intact male pigs grow faster, are more efficient in converting feed and have better carcass quality than castrated males (Patterson and Lightfoot, 1984).

Factors that might decrease the production of testicular steroid synthesis of androstenone and skatole and their accumulation in fat have been investigated extensively. The relationship between boar odor in growing animals and their age and live weight indicate that individual variations in fat androstenone at a given age and weight are considerable (Bonneau, 1982; Patterson and Lightfoot, 1984). Weight is an important factor in such cases because the level of androstenone in fat is affected by the presence of gilts in the pen only when boars weigh more than $110 \mathrm{~kg}$ (Patterson and Lightfoot, 1984). Active immunization against androstenone (Shenoy et al, 1982; Williamson et al, 1985; Brooks et al, 1986) or against luteinizing-hormone-releasinghormone (LHRH) in boars (Caraty and Bonneau, 1986; Falvo et al, 1986) has successfully reduced levels of androstenone in fat, but large variations exist among the studies, and these procedures are difficult and expensive.

Administration of gonadotrophin-releasing hormone (GnRH) and many of its analogs increases pituitary secretion of $\mathrm{LH}$ and follicle-stimulating hormones (FSH) which in turn stimulates the synthesis of steroids by the testis and ovary (Schally, 1978). In contrast, large doses of GnRH or its agonist, after a short period of stimulation, inhibit gonadal function. The mechanism responsible for these paradoxical inhibitory effects is a pituitary desensitization induced by $\mathrm{GnRH}$ agonist blockade of endogenous LH release, with secondary loss of testicular $\mathrm{LH}$ and prolactin receptors (Auclair et al, 1977a, b; Labrie et al, 1978, 1980; Cusan et al, 1979) and a variety of direct effects on the ovary and testis (Hsueh and Erickson,
1979). Chronic treatment with $\mathrm{GnRH}$ agonists to inhibit secretion of sexual steroids has been reported in the male rat (Auclair et al, 1977a, b; Pelletier et al, 1978; Rivier et al, 1979; Bélanger et al, 1980), in the female rat (Hsueh and Erickson, 1979), in male and female dogs (Tremblay et al, 1984; Lacoste et al, 1989a, b), in the rhesus monkey (Weinbauer et al, 1987), in men (Labrie et al, 1980, 1982) and in women (Bergquist et al, 1979).

Our study was designed to determine the effect of a long-acting $\mathrm{GnRH}$ analog as a means of castrating meat-producing pigs on reproductive organs, growth performance, carcass characteristics and the sensory qualities of pork roasts from male and female pigs.

\section{MATERIALS AND METHODS}

\section{Animals}

Two hundred crossbred pigs aged $13 \pm 2$ days were selected, tattooed and randomly assigned to five treatment groups of 40 animals each: intact males (IM), intact females (IF), males castrated 2 weeks after birth (CM), intact males treated with one injection of the GnRH agonist (TM) and intact females also injected with the agonist (TF). At age $66 \pm 2$ days (DO), the pigs left the nursery and were distributed by groups of eight to their specific treatment ( 25 pens) in a growing-finishing barn. Treated groups then received the injection of $\mathrm{GnRH}$ agonist. Twice a day, pens were handfed on the floor to satiation of the pigs with commercial swine chunk, which was weighed every meal. At the beginning of treatment (D0) and at slaughter (D116), the pigs were individually weighed. All animals were electrically stunned, stuck, scalded, dressed and probed following commercial procedures.

\section{GnRH preparation}

Treatment was a single intramuscular injection of a controlled-release formulation of $\mathrm{GnRH}$ agonist [D-Trp ${ }^{6}$, des-Gly $\left.{ }^{10}\right]-G n R H$ ethylamide (GnRH) 
(Southern Research Institute, Birmingham, AL, USA). The controlled release formulation consisting of microspheres was designed to release $5 \mu \mathrm{g} /(\mathrm{kg} \times$ day) of $\mathrm{GnRH}$ for 4 months. A total of $27.6 \mathrm{mg}$ of $\mathrm{GnRH}$ in dry suspension $(440 \mathrm{mg}$ ) form was mixed with $4 \mathrm{ml}$ of a specific diluent just before injection into the neck muscles of the treated pigs.

\section{Reproductive organs}

Ovaries, testes and uteri were removed at slaughter and individually identified. At the slaughterhouse, ten testes from TM, two testes from IM, ten ovaries from TF and two ovaries from IF were fixed in Bouin's solution; the reproductive tissues of the other animals were frozen. The remaining frozen organs were dissected free of ligaments or other nonreproductive tissues and weighed. After fixation, tissues were embedded in paraffin, cut in $10 \mu \mathrm{m}$ serial sections and stained with hematoxylin-eosin for light microscopy. All antral follicles containing nuclei were counted and their area measured at the basement membrane by tracing, using an electronic planimeter through a drawing tube fixed to the microscope. Differences between treatment means were determined by the Fisher's (protected) LSD test (Steel and Torrie, 1980).

Blood samples were taken at the time of slaughter (D116) in all animals. The blood was cooled to $4{ }^{\circ} \mathrm{C}$, transported to the laboratory, centrifuged to extract serum and stored at $-20^{\circ} \mathrm{C}$ until analysis. Progesterone, $\Delta-4$ androstenedione, testosterone, estradiol and $\mathrm{GnRH}$ analog residues were measured in thawed serum using radioimmunoassay as previously described (Bélanger et al, 1980).

\section{Pork roast preparations and instrumental measurements}

At the slaughterhouse, 20 longissimus dorsi roasts randomly chosen from each of the five groups were wrapped in plastic bags and then frozen to $-20{ }^{\circ} \mathrm{C}$ for approximately 1 month. The pork roasts were thawed in the refrigerator $\left(4^{\circ} \mathrm{C}\right)$ for $24 \mathrm{~h}$. After oven-ready weights were taken, the roasts were placed on racks in aluminum pans and cooked in preheated ovens at $163^{\circ} \mathrm{C}$ to an internal temperature of $80^{\circ} \mathrm{C}$ (determined by a thermocouple inserted into the geometric center of the roast). Times to desired internal temperatures were noted, and the roasts were allowed to stand $10 \mathrm{~min}$ after cooking before appropriate cooking data were recorded to calculate cooking rate, percentage drip loss and percentage weight loss. The roasts were then covered with aluminum foil until $10 \mathrm{~min}$ before panel evaluation. The roasts were trimmed of excess fat and sliced on a Hobart electric meat slicer set for $4 \mathrm{~mm}$ slices. The first two slices were discarded and then ten slices were sliced for the panel and put on threedigit coded petri dishes. The remaining muscle was placed in a tied plastic bag and stored for $24 \mathrm{~h}$ at $4^{\circ} \mathrm{C}$ for Warner-Bratzler (WB) shear determinations. A modified WB device (Voisey and Hansen, 1967) was calibrated at $4000 \mathrm{~g}$ full scale, and $1 \mathrm{~cm}$ cores of roasts were used to measure maximum shear force; cross-head speed was $22.86 \mathrm{~cm} / \mathrm{min}$. The mean values were based on readings of five cores.

\section{Pork roast analyses}

Ten trained meat panelists underwent four additional training sessions before the experiment. They were familiarized with the intensity of pork flavor, tenderness and juiciness. Each panelist received a set of five samples of roast pork at room temperature, one from each treatment, which was replicated in 18 sessions. A glass of room temperature water and an unsalted cracker were provided to rinse and remove residual flavors from the mouth between samples.

The perceived intensity of pork flavor (slight to intense), tenderness (very tough to very tender) and juiciness (very dry to very juicy) were recorded using an unstructured $15 \mathrm{~cm}$ descriptive analysis line scale with anchor points $1.5 \mathrm{~cm}$ from each end (Poste et al, 1991). Numerical values were obtained by measuring the distance, in centimeters, of the line score from the left end of the scale. The off-flavor (the degree to which boar taint off-flavor was present) was scored using a nine-point scale from 0 (no off-flavor present) to 8 (extreme off-flavor).

\section{Statistical analyses}

Feed conversion data were analyzed by analysis of variance with the treatment mean square 
compared to the among-pen mean square with 20 degrees of freedom. Treatment mean squares for performance and carcass characteristics were compared to the residual error. The following a priori contrasts were examined: TM vs IM, TM vs CM and TF vs IF.

Data from cooking and instrumental measurements were analyzed as randomized blocks with sessions as blocks. Sensory data were also analyzed by analysis of variance with the treatment mean square compared with the amongroast error (session by treatment interaction). We report the partial correlation of the WB values to sensory tenderness adjusted for the design. All computations were done using SAS, PROC GLM (SAS Institute Inc, 1989).

\section{RESULTS}

Table I presents the mean weights of the uteri and ovaries. Uterine $(79.8 \pm 28 \mathrm{~g})$ and ovarian weights $(3.67 \pm 1.5 \mathrm{~g})$ in IF were heavier $(P<0.05)$ than in TF $(26.5 \pm 21.5 \mathrm{~g}$ and $1.38 \pm 1.8 \mathrm{~g}$, respectively). Figure 1 illustrates the differences; the uterus of a TF is on the left side and that of a IF on the right side. Testicular weights from IM (203 \pm $55 \mathrm{~g})$ were heavier $(P<0.05)$ than those from TM (36.8 \pm 11.8$)$. Table I summarizes these results. Figure 2 shows the testicle of an IM on the left side and of a TM on the right side.

Histological analysis indicates that treated females had a mean of $505.5 \pm 424.18$ antral follicles per ovary, among which $95 \%$ had diameters smaller than $1.12 \mathrm{~mm}$ (data not shown). In intact prepubertal gilts of similar age, follicles are in a more advanced stage of development since $27 \%$ of all antral follicles ( $581 \pm 161$ /ovary) were observed to be in size classes greater than $1.12 \mathrm{~mm}$ in diameter (Dufour et al, 1985). Microscopic

Table I. Means of serum concentrations of progesterone, estradiol, testosterone, $\Delta-4$ androstenedione and weight of uterus, ovary and testicles in pigs 116 days after injection of the $\mathrm{GnRH}$ agonist.

\begin{tabular}{|c|c|c|c|c|c|}
\hline Measurements & $\begin{array}{c}\text { Castrated } \\
\text { males } \\
(\mathrm{CM})\end{array}$ & $\begin{array}{l}\text { Intact } \\
\text { males } \\
(I M)\end{array}$ & $\begin{array}{l}\text { Treated } \\
\text { males } \\
(T M)\end{array}$ & $\begin{array}{l}\text { Intact } \\
\text { females } \\
\text { (IF) }\end{array}$ & $\begin{array}{c}\text { Treated } \\
\text { females } \\
(T F)\end{array}$ \\
\hline $\begin{array}{l}\text { Progesterone } \\
(\mathrm{nmol} / \mathrm{L})\end{array}$ & $0.30 \pm 0.15$ & $0.11 \pm 0.17$ & $0.77 \pm 0.16$ & $0.25 \pm 0.35$ & $0.16 \pm 0.31$ \\
\hline $\begin{array}{l}\text { Estradiol } \\
\text { (pmol/L) }\end{array}$ & $4.65 \pm 5.68$ & $103.0 \pm 85.05$ & $34.5 \pm 27.29$ & $31.5 \pm 36.52$ & $14.5 \pm 10.08$ \\
\hline Testosterone (nmol/L) & $0.68 \pm 0.33^{a}$ & $26.36 \pm 9.87^{b}$ & $12.5 \pm 7.44 c$ & $3.54 \pm 4.86^{\mathrm{ac}}$ & $1.06 \pm 0.4 a$ \\
\hline$\Delta-4$ Androstenedione $(\mathrm{nmol} / \mathrm{L})$ & $0.27 \pm 0.05^{a}$ & $4.35 \pm 1.28^{b}$ & $2.06 \pm 1.33^{c}$ & $1.19 \pm 1.27 \mathrm{ac}$ & $0.25 \pm 0.05^{a}$ \\
\hline Uterus weight (g) & - & . - & - & $26.5 \pm 21.5^{a}$ & $79.8 \pm 28^{b}$ \\
\hline Ovary weight (g) & - & - & - & $1.38 \pm 1.89 \mathrm{a}$ & $3.67 \pm 1.5^{b}$ \\
\hline Testicle weight $(\mathrm{g})$ & - & $203 \pm 55^{a}$ & $36.8 \pm 11.8^{b}$ & - & - \\
\hline
\end{tabular}




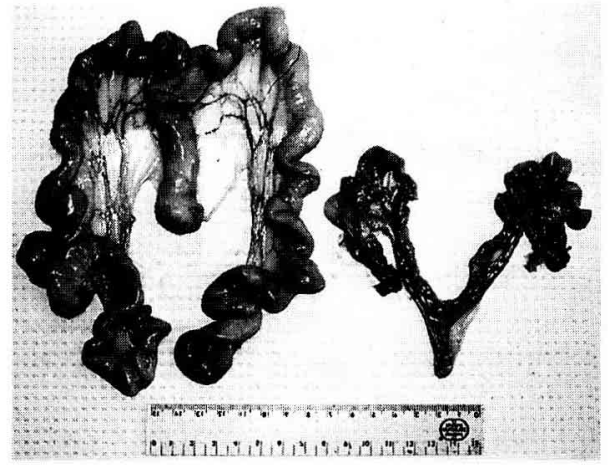

Fig 1. Uterus from a intact female (left side) compared with that from a treated female (right side) 116 days after the injection of the GnRH agonist.

observations of testes from TM revealed an absence of sperm cells but the presence of germ cells, a marked decrease in the diameter of seminiferous tubules and a reduced fluid content in the lumen.

Steroid concentrations in serum taken on D116 at the slaughterhouse from all pigs are summarized in table I. No differences $(P>0.05)$ were observed in progesterone levels. Intact males had the highest concentration of estradiol (103.00 \pm 85.05 $\mathrm{pmol} / \mathrm{L})$ in their serum and $\mathrm{CM}$ the lowest $(4.65 \pm 5.68 \mathrm{pmol} / \mathrm{L})$, but this difference was not statistically significant. The large variation in estradiol concentrations observed in IM pigs indicates that some intact males had obviously reached puberty while others had not, resulting in a large variation between individuals. Intermediate values were observed in other groups. Intact males had significantly more testosterone in their serum $(26.36 \pm 9.87 \mathrm{nmol} / \mathrm{L})$ compared with TM, CM, IF or TF groups. Treated males had intermediate concentrations $(12.50 \pm$ $7.44 \mathrm{nmol} / \mathrm{L})$ higher $(P<0.05)$ than those in $\mathrm{CM}$ and TF. Treated females had lower levels of testosterone in their serum than

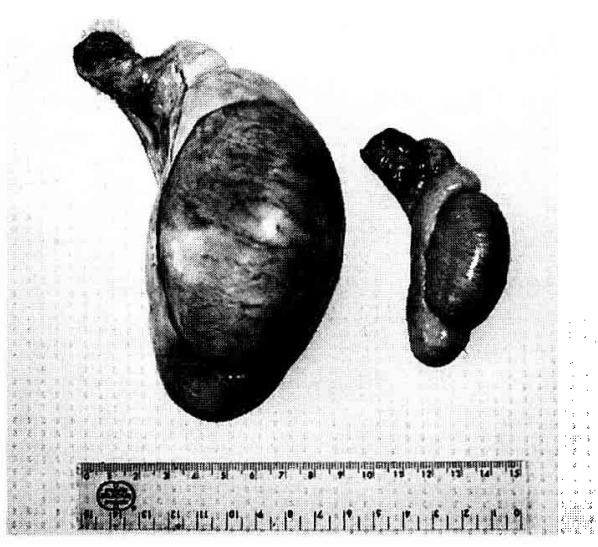

Fig 2. Testicle from an intact male (left side) compared with that from a treated male (right side) 116 days after the injection of the GnRH agonist.

IF, but the difference was not significant. At the time of slaughter, $\mathrm{GnRH}$ agonist in serum was absent in the controls (mean of 15 pigs, five from each group: CM, IM, IF was $2.85 \pm 4.46$ ) and the means for treated females and males were, respectively, $41.14 \pm 13.00$ and $43.43 \pm 16.21 \mathrm{pg} / \mathrm{ml}$. Means from untreated pigs were different from TF and TM groups $(P<0.05)$ but similar in TM and TF $(P>0.05)$.

\section{Growth parameters and carcass measurements}

Table II summarizes the results from the growth parameters and carcass characteristics of the pigs. Weight at the beginning of treatment and at slaughter, average daily gain, feed consumption, feed conversion ratio and grade index were not different for the chosen contrasts $(P>0.05)$. Treated males had higher dressing percentage $(P<$ $0.05)$, reduced meat ratio $(P<0.001)$ and higher average backfat $(P<0.001)$ than IM. Compared with CM, TM also had more backfat $(P<0.05)$. TF had a lower meat 
Table II. Mean values and standard errors for growth parameters and carcass measurements for castrated males, intact males, treated males, intact females and treated females.

\begin{tabular}{|c|c|c|c|c|c|c|}
\hline Measurements & $\begin{array}{c}\text { Castrated } \\
\text { males } \\
\text { (CM) }\end{array}$ & $\begin{array}{l}\text { Intact } \\
\text { males } \\
\text { (IM) }\end{array}$ & $\begin{array}{c}\text { Treated } \\
\text { males } \\
\text { (TM) }\end{array}$ & $\begin{array}{c}\text { Intact } \\
\text { females } \\
\text { (IF) }\end{array}$ & $\begin{array}{c}\text { Treated } \\
\text { females } \\
\text { (TF) }\end{array}$ & $S E^{1}$ \\
\hline Weight at D10 $(\mathrm{kg})$ & 16.7 & 16.2 & 15.4 & 16.5 & 15.8 & 0.6 \\
\hline Weight at D116 $(\mathrm{kg})$ & 87.8 & 85.5 & 84.8 & 89.2 & 88.8 & 1.8 \\
\hline Avg daily gain $2(\mathrm{~kg})$ & 0.61 & 0.609 & 0.612 & 0.626 & 0.635 & 0.012 \\
\hline Feed consumption ( $\mathrm{kg} /$ day) & 1.75 & 1.62 & 1.68 & 1.70 & 1.70 & 0.05 \\
\hline $\begin{array}{l}\text { Feed conversion ratio } \\
\text { ( } \mathrm{kg} \text { feed } / \mathrm{kg} \text { gain) }\end{array}$ & 2.83 & 2.65 & 2.78 & 2.68 & 2.68 & 0.06 \\
\hline Dressing percentage ${ }^{3}(\%)$ & 77.9 & 76.5 & $77.5^{\mathrm{a}}$ & 78.2 & 78.3 & 0.3 \\
\hline Meat ratio $4(\%)$ & 49.7 & 50.2 & $49.1^{\mathrm{b}}$ & 50.7 & $50.1^{*}$ & 0.2 \\
\hline Backfat ${ }^{4}(\mathrm{~mm})$ & 19.4 & 17.6 & $20.8^{b c}$ & 16.9 & $18.7^{*}$ & 0.5 \\
\hline
\end{tabular}

1 For feed consumption and feed conversion ratio based on 20 degrees of freedom; for the remainder based on at least 178 degrees of freedom; ${ }^{2}$ based on D0 weight; ${ }^{3}$ based on D116 weight; ${ }^{4}$ based on carcass weight; a differed from IM at $P<0.05$; ${ }^{\text {b }}$ differed from IM at $P<0.001$; c differed from $\mathrm{CM}$ at $P<0.05^{;}{ }^{*}$ differed from IF at $P<0.05$.

ratio $(P<0.05)$ and a higher backfat $(P<$ $0.05)$ than IF.

\section{Cooking data and sensory data}

Except for drip loss, cooking data showed no significant differences $(P>0.05)$ among treatments (table III). The drip loss results indicated that IM had less drip loss $(P<$ $0.05)$ than TM roasts. Flavor scores were not significantly different; however, there was a significant judge by treatment interaction $(P<0.05)$. Off-flavor scores were found to be higher for IM roasts than TM roasts $(P<0.001)$ and there was a significant judge by treatment interaction $(P<$ 0.001 ). The IM had the highest off-flavor score of 1.4 (slightly perceptible), and the other four treatments received scores between 0.7 and 0.9 (essentially imperceptible). There were no differences in tenderness $(P>0.05)$ or significant judge by treatment interaction; scores ranged from 7.6 to 8.7 (table II). These results were confirmed by WB results that indicated no significant differences among treatment shear force values. The partial correlation between WB and tenderness was $-0.46(P<0.001)$. Juiciness scores were significantly different, with TF roasts juicier than the IF roasts $(P<$ 0.05).

\section{DISCUSSION}

The present results indicate that chronic treatment of male pigs at age 66 days with a single injection of a long-acting form of $\mathrm{GnRH}$ agonist, planned to released $5 \mu \mathrm{g} / \mathrm{kg}$ $x$ day) for a period of 4 months, resulted in reduction of gonadal functions as determined by serum concentrations of testosterone, $\Delta-4$ androstenedione and estradiol, 116 days after the beginning of the experiment. Indeed, testicular development was greatly affected by the administration of GnRH agonist. At slaughter, TM had a testicular weight 5.5-fold smaller than IM. In the adult rhesus monkey (Weinbauer et al, 
Table III. Mean values and standard errors for cooking, sensory and instrumental measurements of pork roasts.

\begin{tabular}{|c|c|c|c|c|c|c|c|c|}
\hline Measurements & $\begin{array}{c}\text { Castrated } \\
\text { males } \\
(C M)\end{array}$ & $\begin{array}{l}\text { Intact } \\
\text { males } \\
(I M)\end{array}$ & $\begin{array}{l}\text { Treated } \\
\text { males } \\
\text { (TM) }\end{array}$ & $\begin{array}{l}\text { Intact } \\
\text { females } \\
\text { (IF) }\end{array}$ & $\begin{array}{c}\text { Treated } \\
\text { females } \\
\text { (TF) }\end{array}$ & SE 1 & $\begin{array}{c}\text { Signif } \\
\text { of treatment }\end{array}$ & $\begin{array}{c}\text { Signif } \\
\text { of panelist } \\
\text { * } \\
\text { treatment } \\
\text { interaction }\end{array}$ \\
\hline Oven-ready weight (g) & 647.1 & 641.2 & 664.3 & 652.7 & 674.6 & 22.6 & NS ${ }^{2}$ & \\
\hline Cooking rate $(\mathrm{min} / 100 \mathrm{~g})$ & ) 20 & 20 & 20 & 20 & 19 & 0.5 & NS & \\
\hline Weight loss (\%) & 29.7 & 29.5 & 29.9 & 30.2 & 28.9 & 0.69 & NS & \\
\hline Drip loss (\%) & 7.4 & 5.4 & $6.6^{a}$ & 7.1 & 6.6 & 0.35 & $P<0.01$ & \\
\hline Flavor $(\mathrm{cm})$ & 7.8 & 7.5 & 7.9 & 8.1 & 7.9 & 0.17 & NS & $P<0.05$ \\
\hline Off-flavor & 0.9 & 1.4 & $0.7^{b}$ & 0.7 & 0.8 & 0.12 & $P<0.001$ & $P<0.001$ \\
\hline Tenderness $(\mathrm{cm})$ & 8.3 & 8.7 & 8.1 & 7.6 & 8.5 & 0.42 & NS & NS \\
\hline Juiciness $(\mathrm{cm})$ & 8.2 & 9 & 8.3 & 7.3 & $8.2^{\star}$ & 0.25 & $P<0.001$ & NS \\
\hline \multicolumn{9}{|l|}{ Warner-Bratzler } \\
\hline shear (Newtons) ${ }^{3}$ & 28.5 & 24.1 & 26 & 25 & 26.7 & 2 & NS & \\
\hline
\end{tabular}

1 Standard error of the means based on 68 degrees of freedom; ${ }^{2} \mathrm{NS}$ : no significance $(P>0.05)$; ${ }^{3}$ WarnerBratzler shear correlation with tenderness $r=-0.46(P<0.001)$; a differed from IM at $P<0.05$; b differed from IM at $P<0.001$; * differed from IF at $P<0.05$.

1987) and mature rat (Rivier et al, 1979; Ward et al, 1989), GnRH agonist taken over a long period of time also decreased the weight of the testes. Administration of a $\mathrm{GnRH}$ antagonist over a 3 week period in neonatal pigs resulted in the diminution of testes weights (Ziecik et al, 1989). Active immunization of boars against LHRH also induced a reduction in testicular weight (Falvo et al, 1986; Grizzle et al, 1987; Bonneau et al, 1994) and volume (Esbenshade and Johnson, 1987). Such a decrease in testicular weight observed in the present is mostly due to a decrease in the diameter of seminiferous tubules and in the volume of Leydig cells.

Likewise, ovarian development was markedly decreased at the end of $\mathrm{GnRH}$ treatment. This decrease in weight of the reproductive organs was mostly due to the fact that almost all antral follicles observed in $\mathrm{GnRH}$-treated gilts (95\%) were inhibited from growing to large-size classes known to secrete estrogens. As demonstrated by Esbenshade (1987), such small-size follicles cannot be stimulated by pregnant mare serum gonadotropin (PMSG) following an active immunization against $\mathrm{GnRH}$. As a result of ovarian inhibition observed in TF, serum levels of progesterone, estradiol, androstenedione and testosterone, although not statistically different from IF, were always lower, indicating therefore an inhibitory action by $\mathrm{GnRH}$ agonist on ovarian function. No comparable studies are available on the effect of GnRH agonist on serum steroid levels of prepubertal female pigs, but active immunization of pubertal gilts, starting at age 7 months and ending 4 months later, inhibited secretion of gonadal steroids (Esbenshade and Britt, 1985).

Concentrations of $\mathrm{GnRH}$ agonist in serum of treated males and females at slaughter were only approximately $3 \%$ of those levels observed 24 days after the injection (measured in four pigs of the two 
sexes; data not shown), when $\mathrm{GnRH}$ agonist levels were at their maximum, indicating therefore, that male and female pigs eliminate $\mathrm{GnRH}$ analog at a similar rate. Lacoste et al (1989a) indicated that blockade of steroid secretions by a LHRH agonist longacting form in males and females is rapidly reversible because a return to normal serum levels of steroids occurred within 1 month after cessation of release of LHRH-A. This could explain then why serum concentrations of estradiol, $\Delta-4$ androstenedione and testosterone obtained at the end of the experiment in $\mathrm{TM}$ were higher than in $\mathrm{CM}$ but not quite the same as IM. Although the levels of $\mathrm{GnRH}$ agonist at the site of injection were not measured, it is more likely that some were still present since treated pigs had some peptide in the blood. To make sure that the $\mathrm{GnRH}$ agonist could be considered as a feasible method for enhancing meat production by the pork industry, the site of injection should be revised to include a remote area not considered as being important by the consumers, such as the ear.

Average daily gain and average daily feed consumed did not differ among selected contrasts and are in agreement with the findings of other investigators (Charette, 1961; Newell and Bowland, 1972; Desmoulin and Bonneau, 1979; Denzer et al, 1986) when IM and CM are compared. It should be noted that in the present experiment, pigs were group fed, and slaughtered at a fixed time irrespective of their expected required weight for classification. Whether a more precise way of measuring feed consumption would have allowed for a difference in growth performance between treated and intact animals is unknown, but similar results have been observed in pigs actively immunized against LHRH where castrated and intact males receiving only the adjuvant were seen to have similar growth development (Falvo et al, 1986). However, more recently, Bonneau et al (1994), when comparing immunized intact pigs with untreated intact pigs, were able to show a difference in growth performance between these two types of animals.

Differences in the dressing percentage between IM and TM were unexpected since CM pigs were found to be similar to the IM group. Contradictory results have been published before when comparing IM and CM. Newell and Bowland (1972), Desmoulin (1973) and Desmoulin and Bonneau (1979) found that intact males had the lowest dressing percentage when compared with castrated males while, Charette (1961) found no difference in dressing percentage between IM and $\mathrm{CM}$ pigs. These variations could be explained by differences among breeds (Desmoulin and Bonneau, 1979; Sather et al, 1991) or in the level of protein present in the diet (Newell and Bowland, 1972). In the present study, no differences were found in dressing percentage for IF and TF. Backfat measurements were found to be greater in TM pigs when compared to IM or CM, in agreement with the results of Newell and Bowland (1972), Brooks et al (1986) and others (Desmoulin and Bonneau, 1979; Kluber et al, 1988; Schanbacher et al, 1985; Judge et al, 1990). As observed in the present study, Falvo et al (1986) reported that boars actively immunized against LHRH had more backfat than IM or CM.

In the present experiment, TF had higher backfat values than IF, comparable to the results of Desmoulin (1973), who reported that IF had less external fat than castrated females, but his results were not statistically significant. As indicated previously, no attempts were made to ship the pigs at their ideal weight for maximum index because all pigs had to be slaughtered on the same day. The difference between the TF and IF in body composition indicates that estrogens may be important in growth performance as well as carcass composition as also demonstrated before by Desmoulin (1973). 
Based on tenderness, juiciness scores, off-flavor scores and the incidence of boar flavor of pig roasts, $\mathrm{GnRH}$ agonist treatment could be thought of as an alternative to surgical castration in meat production. Such results have been observed previously by Falvo (1986) with immunized pigs. The significant judge by treatment interaction in offflavor and the incidence of boar flavor observed in the present study can be explained by the fact that some panelists perceived the boar taint at a more intense level than others. This is in agreement with the results of Griffiths and Patterson (1970), who reported that sensitivity toward boar taint smell varies markedly from person to person and that, generally speaking, women are more sensitive than men. It should be noted, however, that in the present study, boar taint smell was not determined.

\section{IMPLICATIONS}

The present study demonstrates that administration of a 4 month formulation of the GnRH agonist microcapsules can efficiently reduce gonadal steroid secretions to castration level during the growth period in prepubertal male pigs and can be used as an alternative to surgical castration to enhance meat production by the pork industry with minimal effects on growth performance, carcass characteristics or sensory quality of the roast. With females, however, there is no advantage for endocrine castration. Since the product is quickly metabolized in the animal, this technique could become acceptable to the consumer. Use of this technique to replace surgical castration may also be more acceptable on an animal welfare point of view.

\section{ACKNOWLEDGMENTS}

This study was supported by Agriculture Canada, Laval University and the CHUL Research Cen- ter, $P Q$, Canada. The authors are thankful to $\mathrm{Dr}$ $F$ Labrie, director of the Centre de Recherche du $\mathrm{CHUL}$, for his expertise and the GnRH agonist used in this study. The help of L Post (Ag Canada) for the sensory qualities analysis and $G$ Butler (Ag Canada) for the statistical analysis is gratefully acknowledged.

\section{REFERENCES}

Auclair C, Kelly PA, Coy DH, Schally AV, Labrie F (1977a) Potent inhibitory activity of [D-leu6, des-Gly$\mathrm{NH} 210$ ]LHRH ethylamide on LH/hCG and PRL testicular receptor levels in the rat. Endocrinology 101, 1890-1893

Auclair C, Kelly PA, Labrie F, Coy DH, Schally AV (1977b) Inhibition of testicular luteinizing hormone receptor level by treatment with a potent luteinizing hormone-releasing hormone agonist or human chorionic gonadotropin. Biochem Biophys Res Commun $76,855-862$

Bélanger A, Auclair C, Ferland S, Caron, S, Labrie F (1980) Time-course of the effect of treatment with a potent LHRH agonist on testicular steroidogenesis and gonadotropin receptor levels in the adult rat. J Steroid Biochem 13, 191-196

Berquist C, Nillius SJ, Wide L (1979) Intranasal gonadotropin-releasing hormone agonist as a contraceptive agent. Lancet (Lond) 2, 215-217

Bonneau M (1982) Compounds responsible for boar taint, with special emphasis on androstenone; a review. Livest Prod Sci 9, 687-705

Bonneau M (1988) Advantages and disadvantages of meat production from entire male pigs. Prod Anim INRA 1, 133-140

Bonneau M, Dufour R, Chouvet C, Roulet C, Meadus W, Squires EJ (1994) The effects of immunization against LHRH on performance, sexual development, and levels of boar taint-related compounds in intact male pigs. J Anim Sci 72, 14-20

Brooks RI, Pearson AM (1986) Steroid hormone pathways in the pig, with special emphasis on boar odor; a review. J Anim Sci 62, 632-645

Brooks RI, Pearson AM, Hogberg MG, Pestka JJ, Gray $\mathrm{Jl}$ (1986) An immunological approach for prevention of boar odor in pork. J Anim Sci 62, 1279-1289

Caraty A, Bonneau M (1986) Immunisation active du porc mâle contre la gonadorlibérine, effets sur la sécrétion d'hormones gonadotropes et sur la teneur en 5d-alpha-androst-16-ene-3-one du tissu adipeux. CA Acad Sci Paris, série III, 303, 673-676

Charette LA (1961) The effects of sex and age of male at castration on growth and carcass quality of Yorkshire swine. Can J Anim Sci 41, 30-39 
Cusan L, Auclair C, Bélanger A, Ferland L, Kelly PA, Seguin C, Labrie F (1979) Inhibitory effects of longterm treatment with a luteinizing hormone-releasing hormone agonist on the pituitary-gonadal axis in male and female rats. Endocrinology 104, 1369 1376

Denzer LE, Thompson LH, McKeith FK, Parrett DF, Thomas DL (1986) Evaluation of growth, carcass traits and reproductive organs of young boars in response to zeranol implantation. J Anim Sci 62, 1164-1171

Desmoulin B (1973) Qualités de carcasse des porcs Large-White. Aptitudes aux rationnements suivant le sexe et après la castration. Jour Rech Porc Fr 5 , 189-199

Desmoulin B, Bonneau M (1979) Production de viandes de porcs mâles entiers ou castrés, efficacité et composition corporelle chez les races hypermusclées. Ann Zootech 28, 35-51

Desmoulin B, Bonneau M, Frouin A, Bidard JP (1982) Consumer testing of pork and processed meat from boars, the influence of fat androstenone level. Livest Prod Sci 9, 707-715

Esbenshade $\mathrm{KL}$ (1987) Ovarian response to pregnant mare serum gonadotropin and porcine pituitary extract in gilts actively immunized against gonadotropin-releasing hormone. J Anim Sci 65, 1768-1774

Esbenshade KL, Britt JH (1985) Active immunization of gilts against gonadotropin-releasing hormone. Effects on secretion of gonadotropins, reproductive function, and responses to agonists of gonadotropinreleasing hormone. Biol Reprod 33, 569-577

Esbenshade KL, Johnson BH (1987) Active immunization of boars against gonadotropin-releasing hormone. II. Effects on libido and response to testosterone propionate. Theriogenology 27, 581-585

Falvo RE, Chandrashekar V, Arthur RD, Kuenstler AR, Hasson T, Awoniyi C, Schanbacher BD (1986) Effect of active immunization against $\mathrm{LHRH}$ or $\mathrm{LH}$ in boars, reproductive consequences and performance traits. $J$ Anim Sci 63, 986-994

Griffiths NM, Patterson RLS (1970) Human olfactory reponses to $5 \partial$-androst-16-en-3-one - principal component of boar taint. J Sci Food Agric 21, 4-6

Grizzle TB, Esbenshade KL,Johnson BH (1987) Active immunization of boars against gonadotropin-releasing hormone. I. Effects on reproductive parameters. Theriogenology 27, 571-580

Hsueh AJ, Erickson GF (1979) Extrapituitary action of gonadotropin-releasing hormone, direct inhibition ovarian steroidogenesi. Science 204, 854-855

Judge MD, Mills EW, Orcutt MW, Forrest JC, Diekman MA, Harmon BG, Lin RS, Nicholls LL (1990) Utilization of boar meat, composition, quality and odor incidence in relation to androstenone and skatole. $J$ Anim Sci 68, 1030-1033
Kluber EF III, Minton JE, Stevenson JS, Hunt MC, Davis DL, Hoagland TA, Nelssen JL (1988) Growth, carcass traits, boar odor and testicular and endocrine functions of male pigs fed a progestogen, altrenogest. J Anim Sci 66, 470-479

Labrie F, Auclair C, Cusan L, Kelly PA, Pelletier G, Ferland $L$ (1978) Inhibitory effect of LHRH and its agonists on testicular gonadotropin receptors and spermatogenesis in the rat. In: 5 th annual workshop on the testis; Endocrine Approach to Male Contraception. Int $J$ Androl suppl 2, 303-308

Labrie F, Bélanger A, Cusan L, Séguin C, Pelletier G, Kelly $P$, Reeves JJ, Lefebvre FA, Lemay A, Gourdeau Y, Raynaud JP (1980) Antifertility effects of LHRH agonists in the male. J Androl 1, 209-228

Lacoste D, Dubé D, Trudel C, Bélanger A, Labrie F (1989a) Normal gonadal functions and fertility after 23 months of treatment of prepubertal male and female dogs with the GnRH agonist [D-Trp ${ }^{6}$, desGly- $\mathrm{NH}_{2}{ }^{10} \mathrm{JGnRH}$ ethylamide. J Androl $10,456-465$

Lacoste D, Labrie F, Dubé D, Bélanger A, Tice T, Gilley RM, Pledger KL (1989b) Reversible inhibition of testicular androgen secretion by 3-, 5- and 6-month controlled-release microsphere formulations of the $\mathrm{LH}-\mathrm{RH}$ agonist [D-Trp ${ }^{6}$, des-Gly-NH $\left.{ }^{10(2)}\right] \mathrm{LH}-\mathrm{RH}$ ethylamide in the dog. J Steroid Biochem 33,1007 1011

Lundstrom K, Malmfors B, Malmfors G, Stern S, Peterson H, Mortensen AB, Sorensen SE (1988) Skatole, androstenone and taint in boars fed two different diets. Livest Prod Sci 18, 55-67

Newell JA, Bowland JP (1972) Performance, carcass composition, and fat composition of boars, gilts, and barrows fed two levels of protein. Can J Anim Sci $52,543-551$

Patterson RLS, Lightfoot AL (1984) Effect of sex grouping during growth on 5-alpha-androstenone development in boars at three commercial slaughter weights. Meat Sci 10, 253-263

Pelletier G, Cusan L, Auclair C, Kelly PA, Désy L, Labrie $F(1978)$ Inhibition of spermatogenesis in the rat by treatment with [D-Ala ${ }^{6}$, des-Gly- $\mathrm{NH}_{2}{ }^{6}$ ]-LHRH ethylamide. Endocrinology 103, 641-643

Poste LM, Mackie DA, Butler G, Larmond E (1991) Laboratory methods for sensory analysis of foods. Publication 1864E, Agriculture Canada, Ottawa, $90 \mathrm{p}$

Rivier C, Rivier J, Vale W (1979) Chronic effects of [D$\left.\operatorname{Tr} p^{6}, \mathrm{Pro}^{9}-\mathrm{NE} t\right]$ luteinizing hormone-releasing factor on reproductive processes in the male rat. Endocrinology 105, 1191-1201

SAS Institute Inc (1989) SAS/STAT User's Guide, Version 6, 4th edn, vol 2, Cary, NC, USA, $846 \mathrm{p}$

Sather AP, Jones SD, Joyal S (1991) Feedlot performance, carcass composition and pork quality from entire male and female Landrace and Large White market-weight pigs. Can J Anim Sci 71, 29-42 
Schally AV (1978) Aspect of hypothalamic regulation of the pituitary gland. Its implications for the control of reproductive processes. Science 202, 18-28

Schanbacher BD, Yen JT, Pond WG (1985) Testosterone and the incidence of boar taint effects of testosterone or testosterone propionate on the incidence of boar taint in implanted barrows. Meat Sci $13,237-246$

Shenoy EVB, Daniel MJ, Box PG (1982) The boar taint steroid 5-alpha androst-16-en-3-one; an immunization trial. Acta Endocrinol 100, 131-136

Steel RGD, Torrie JH (1980) Principles and Procedures of Statistics. A Biometrical Approach, 2nd edn. McGraw-Hill New York, USA

Tremblay $Y$, Bélanger A, Labrie F, Frenette G, Dubé JY, Tremblay RR (1984) Characteristics of the inhibitory effect of chronic treatment with an LHRH agonist on testicular steroidogenesis in the dog. Prostate 5, 631-638
Voisey PW, Hansen H (1967) A shear apparatus for meat tenderness evaluation. Food Technol 21, 355361

Ward JA, Furr BJ, Valcaccia B, Curry B, Bardin CW, Gunsalus GL, Morris ID (1989) Prolonged suppression of rat testis function by a depot formulation of Zoladex, a GnRH agonist. J Androl 10, 478-486

Weinbauer GF, Respondek M, Themann H, Nieschlag E (1987) Reversibility of long-term effects of GnRH agonist administration on testicular histology and sperm production in the nonhuman primate. $J$ Androl 8, 319-329

Williamson ED, Patterson RLS, Buxton ER, Mitchell KG, Partridge IG (1985) Immunization against $5 \partial$ androstenone in boars. Livest Prod Sci 12, 251-264

Ziecik AJ, Esbenshade KL, Britt JH (1989) Effects of a gonadotrophin-releasing hormone antagonist on gonadotrophin secretion and gonadal development in neonatal pigs. J Reprod Fertil 87, 281-289 